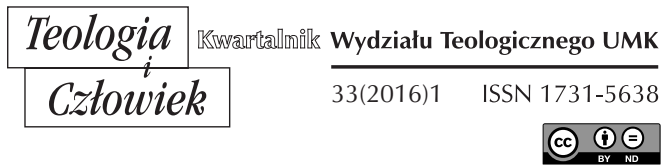

KS. WOJCIECH MEDWID*

KRAKÓW

\title{
TOMASZA MORE'A KONCEPCJA NAPRAWY CHRZEŚCIJAŃSKIEGO SPOŁECZEŃSTWA
}

DOI: http://dx.doi.org/10.12775/TiCz.2016.004

\section{WPROWADZENIE}

Wśród różnych koncepcji i idei społeczeństwa i roli w nim człowieka oraz Kościoła na przestrzeni wieków interesującym jawi się chrześcijański humanizm. Był on próbą scalenia idei humanistycznych z chrześcijanizmem. Za jednego z najwybitniejszych myślicieli renesansu uważa się Erazma z Rotterdamu (1466-1536). Bliski jego koncepcji był Tomasz More (1478-1535). Obaj w swoich dziełach promowali założenia chrześcijańskiego humanizmu, zmierzające do reformy wielu sfer życia europejskiego. Erazm widział konieczność przeprowadzenia konstruktywnych zmian w Kościele katolickim. Krytykował nadużycia duchownych przejawiające się w braku pobożności, dbaniu o własne dobro kosztem wiernych oraz

* Ks. dr Wojciech Medwid, prezbiter diecezji bielsko-żywieckiej Kościoła rzymskokatolickiego, absolwent Wydziału Teologicznego Papieskiego Uniwersytetu Jana Pawła II w Krakowie, obecnie pracuje w parafii św. Stanisława w Andrychowie (wojmed@gmail.com). 
niskim poziomie wykształcenia, jak również $\mathrm{w}$ handlu relikwiami, i średniowieczną scholastykę. Jednocześnie zachęcał wiernych świeckich do czytania Pisma Świętego. Trzeba podkreślić, że w jego programie nigdy nie pojawiła się reformacja jako ruch zmierzający do oderwania się od wspólnoty Kościoła. Dążył raczej do jej odnowienia w duchu prostoty ${ }^{1}$.

Z kolei Tomasz More, jako ortodoksyjny katolik, mocno sprzeciwiał się ruchom reformatorskim, a będąc dyplomatą, doradcą królewskim na dworze Henryka VIII i kanclerzem Anglii, żył według Bożych zasad, dochowanie wierności którym przypłacił śmiercią. Należy zaznaczyć, że piśmiennictwo More’a i jego postawa miały duże znaczenie w dobie renesansu europejskiego i reformacji protestanckiej. Celem artykułu jest ukazanie, w jaki sposób T. More chciał zreformować europejskie społeczeństwo w duchu chrześcijańskiego humanizmu i zaangażować się w to dzieło na dworze królewskim jako osoba kierująca się filozofia Chrystusa. Znaczący wpływ na kształt reformy Tomasza niewątpliwie miał Erazm. Pomocnym odniesieniem refleksji będzie jego traktat retoryki artystycznej - Utopia, składający się z dwóch ksiąg. W pierwszej autor rozmawia z podróżnikiem Rafałem o współczesnym mu świecie, w którym żyje, czyli o filozofach, ich rządach i dlaczego mądrzy ludzie nigdy nie zostaną doradcami królewskimi. W drugiej części ów podróżnik snuje opowieść na temat wyspy Utopii, która ujęła go swoim systemem rządów. W Utopii zostały zawarte poglądy na istotne kwestie renesansowego świata takich, jak: polityka, religia, obyczajowość i etyka. Niektórzy współcześni uczeni dopatrywali się w tym dziele wyidealizowanego przeciwieństwa Europy z czasów Tomasza, inni zaś uznawali je za uszczypliwą satyrę na ówczesną Europę².

\section{UJĘCIE CHRZEŚCIJAŃSKIEGO HUMANIZMU ERAZMA I MORE'A}

Chrześcijański humanizm wprowadzany w życie przez przyjaciela More’a - Erazma z Rotterdamu stał się filozofią oddziałującą na ówczesne

1 Por. A. Cornelis, Erasmus: His life, works, and Influence, Toronto 1991, s. 31-42; J. McConica, Erasmus, Oxford 1991, s. 27-33; J. Nelson, Sir Thomas More, Christian Humanism and Utopia, „Archive” 59 (2004), s. 59-62.

2 Por. D. Baker, Divulging Utopia: Radical Humanism in Sixteenth Century England, Massachusetts 1999, s. 2-3; A. Kenny, Thomas More, Oxford 1983, s. 5-8. 
problemy społeczne, polityczne i religijne. Ich katolicki kształt T. More próbował ratować przez reformy, a później przez obronę ortodoksyjnych przekonań i praktyk Kościoła. Należy wspomnieć, że celem humanizmu chrześcijańskiego było usprawnienie Europy, koncentrujące się na wartościach, co Erazm określił jako filozofię Chrystusa (philosophia Christi). Zrodziła się ona z pragnienia reformy zarówno w Kościele katolickim, jak również w społeczeństwie oraz z chęci ponownego odkrycia starożytnej literatury klasycznej. Humaniści mieli nadzieję, że studium nad starożytnymi tekstami w oryginalnych językach będzie owocowało przywróceniem w Europie dawno już zapomnianych umiejętności, które stosowano do tekstów biblijnych i starożytnych pisarzy chrześcijańskich. Miało to być pomocą europejskiemu chrześcijaństwu w jasnym i autentycznym zrozumieniu chrześcijańskich prawd wiary. Erazm wraz z humanistami byli zdania, że owe podstawowe prawdy zawierają się w philosophia Christi. Najpierw zachęcał ludzi do pobożnego życia (Enchiridion Militis Christiani³), a później wytykał błędy w satyrycznych atakach (Moriae Encomium $\left.^{4}\right)^{5}$.

Erazm i More byli zdania, że chrześcijaństwo powinno ukazywać autentyzm postępowania w naśladowaniu Chrystusa oraz pomagać każdemu człowiekowi, kierującemu się dobrem. T. More wierzył w zreformowanie ówczesnej Europy, pod warunkiem przyjęcia przez ludzi humanistycznej edukacji, służenia sobie wzajemnie i postępowania według filozofii Chrystusa. Utopia powstała w czasie, gdy jeszcze nie były w tak ostry sposób krytykowane wady duchowieństwa i hierarchii kościelnej i nie roztaczała się wizja schizmy. Tomasz ukazał wiele błędów współczesnej mu Anglii, jednakże sednem jego dzieła było humanistyczne przesłanie, wyrażające się $\mathrm{w}$ przekonaniu, iż przy pomocy mądrości i biblijnych przykładów, mówiących o służeniu w czynnej miłości, jak i dzięki przewodnictwu Kościoła, społeczeństwo jest w stanie poprawić się do czasu przyjścia Chrystusa na końcu czasów. W rozważaniach

${ }^{3}$ Por. Desiderius Erasmus, A Book Called in Latin Enchiridion Militis Christiani, and in English the Manual of the Christian Knight, London 2012.

${ }_{4}$ Por. tenże, Moriae Encomium, London 2012.

${ }^{5}$ Por. C. Nauert, Humanism and the Culture of Renaissance Europe, Cambridge 2006, s. 12-18; R. Schoeck, Erasmus of Europe: The Prince of Humanists, 1501-1536, Edinburgh 1993, s. 25-28. 
T. More’a pojawił się dylemat, czy człowiek roztropny i kierujący się Bożymi zasadami powinien wejść na drogę publicznej służby, nawet jeśli podaje $\mathrm{w}$ wątpliwość, że będzie w stanie obronić swoje przekonania. Odpowiedź była twierdząca, ponieważ jeśli król czy kardynał jest w stanie żyć filozofia Chrystusa, to osoby wokół nich także mogą otrzymać łaskę zreformowania siebie i jednocześnie wzmocnią się przykładem swoich zwierzchników. Trzeba podkreślić przekonanie More’a, iż bez Biblii, jak i bez pomocy Chrystusa oraz Kościoła katolickiego żadne społeczeństwo nie może być naprawdę dobre ${ }^{6}$.

\section{ZAŁOŻENIA FILOZOFII CHRYSTUSA}

Kiedy urodził się T. More (1478), Anglia cieszyła się stabilnością, natomiast gdy zdobywał wykształcenie - określając swoje polityczne i religijne poglądy - wytworzył się klimat niepokoju i huśtawek politycznych (wojny domowe, obalanie królów). Tak więc przez cały czas miał wiele obaw względem rozruchów i widział konieczność porządku i pokoju, choć pod względem religijnym Europa wówczas tworzyła jedną katolicką całość pod zwierzchnictwem biskupa Rzymu. Jednakże prymat papieski i chrześcijańska jedność przez różne czynniki i nie zawsze ewangeliczny styl życia duchowieństwa (zeświecczenie, zepsucie, zła obyczajowość) zaowocowały tym, że Kościół katolicki nie miał duchowego i autorytatywnego wpływu na wiernych przed protestancką reformacją. More wciąż upominał się o potrzebę reformy przez ludzi wiary i sumienia. Ponadto niewola awiniońska papieży (1309-1377) oraz tzw. schizma papieska (1378-1417) w znaczący sposób osłabiły pozycję i rolę biskupa Rzymu, a tym samym był to głośny sygnał do reformy w obrębie samego Kościoła. Odpowiedzią na taki stan rzeczy był zwołany do Konstancji sobór powszechny (1414-1418), który starał się wyeliminować schizmę i przywrócić utracony blask Następcy św. Piotra ${ }^{7}$.

${ }^{6}$ Por. J. Bentley, Humanists and Holy Writ: New Testament Scholarship in the Renaissance, New York 1983, s. 45-49; R. Marius, Thomas More, New York 1984, s. 48-56; D. Baker-Smith, Challenging humanism, Newark 2005, s. 54-57.

7 Por. J. Gillingham, The Wars of the Roses, Louisiana 1981, s. 48-53; A. Kenny, dz. cyt., s. 7-9; B. Reardon, Religious Thought in the Reformation, London 1995, s. 2-5. 
Tomasz More receptę na merytoryczną reformę społeczeństwa znalazł w chrześcijańskim humanizmie. Klasyczna literatura starożytności mogła być lustrem, w którym odbijałaby się cywilizacja chrześcijańska. Można powiedzieć, że renesans wzbudził nowego krytycznego ducha kontrastującego z ciasnotą i formalizmem dotychczasowej tradycji teologicznej, jak również stał w opozycji do scholastyki i jej dążeń do usystematyzowania wiary za pomocą narzędzi filozofii spekulatywnej. Ujęcie scholastyczne było pod dyktando arystotelesowskiej logiki i zakładało, iż prawdy wiary chrześcijańskiej zawarte w przesłaniu biblijnym i tradycji mogą bez sprzeczności zostać wyrażone przez uporządkowany system, co potwierdzają dokonania św. Tomasza z Akwinu (1225-1274). Przywrócenie społeczeństwu Starego Kontynentu dawno zapomnianych naukowych narzędzi, stosowanych przy analizie tekstów biblijnych i patrystycznych wydawało się koniecznym wyborem. Celem tych zabiegów miała być pomoc chrześcijaństwu $\mathrm{w}$ jasnym i autentycznym zrozumieniu prawd wiary, co wiązało się ze studium Pisma Świętego w językach oryginalnych. Warto wspomnieć, iż T. More wraz z humanistami zdobywali swoje wykształcenie tradycji scholastycznej w duchu tomizmu zrównoważonego między ludzkim rozumem, który dochodzi do pewnych oczywistych prawd, a objawieniem doktryny chrześcijańskiej przez Biblię i Kościół, który wpłynął na edukację More’a. W naturalny sposób przejęli oni wiele z nauki tomistycznej i metody scholastycznej, odpowiadającej na pytania dotyczące wiary i ewentualnych związanych z nią sprzeczności i niejasności. Jednakże humaniści widzieli w scholastycznym systemie dochodzenia do prawdy bolesne podziały i postanowili wyjść poza niego ${ }^{8}$.

Trzeba powiedzieć, że dla Tomasza i Erazma teksty biblijne i pisma ojców Kościoła stanowiły priorytet w porównaniu z innymi komentarzami średniowiecznych tekstów. W starożytnych pismach dostrzegali oni źródło, dzięki któremu chrześcijaństwo mogło nakreślić odnowioną witalność intelektualną oraz normy do przeprowadzenia reform Kościoła i społeczeństwa. Katoliccy humaniści w optymistyczny sposób patrzyli na możliwość reformy, ponieważ mieli nadzieję, że dzięki tym fundamentalnym tekstom będą mogli odnaleźć i ponownie stworzyć w społeczeństwie świat, w którym ludzie żyją bezinteresownie i cnotliwie oraz

${ }^{8}$ Por. A. Kenny, dz. cyt., s. 16-18; B. Reardon, dz. cyt., s. 16-17. 
pokazując prawdziwe chrześcijaństwo przez żywy przykład. Misją Erazma z Rotterdamu było ukazanie i wdrażanie w życie philosophii Christi, gdzie prawdziwa droga pobożności realizowała się w naśladowaniu Chrystusa. $\mathrm{Z}$ tego względu dla chrześcijan nic nie powinno mieć znaczenia, jak tylko sens i przesłanie samego Chrystusa - prostota, cierpliwość i czystość. Tak więc najlepszym sposobem, aby w pełni zrozumieć przesłanie Chrystusa, jest Pismo Święte i starożytne pisma. W swoim dziele Enchiridion Militis Christiani Erazm wskazał, że podstawą philosophia Christi jest prawdziwe naśladowanie życia Chrystusa (imitatio Christi) oraz potrzeba życia wewnętrznego. Zminimalizował znaczenie zewnętrznych obrzędów, które schlebiają tylko przesądom. Dla Erazma wnętrze ludzkie ma być czyste i odznaczające się prostotą, ponieważ w czystym sercu powstają dobre uczynki. Przeniósł to na sferę liturgii Kościoła, którą ma charakteryzować wzór prostoty pierwotnego Kościoła, oraz na duchownych, którzy powinni spełniać swoją funkcję i powołanie w duchu apostolskim. Z kolei T. More podkreślał znaczenie Kościoła jako instytucji oraz to, aby duchowni byli godni piastującego urzędu, co miało się wyrażać w lepszym prowadzeniu ludzi do zbawienia. Zarówno Erazm, jak i More opowiadali się za powrotem do naśladowania Chrystusa, aby oczyścić świat z tego, co nieewangeliczne i co nie prowadzi do Boga. Według Richarda Mariusa Erazm stał na stanowisku, że dobry chrześcijanin to dobry obywatel oraz że ludzie wykształceni mogą w odpowiedni sposób zdefiniować charakter religii. Przez to wyraża się również dobra służba człowieka w społeczeństwie, w którym żyje?.

Erazm poddał krytyce przekupstwo, hipokryzję i rozwiązłość duchownych, mając poglądy zbliżone do szesnastowiecznych reformatorów. W sposób błyskotliwy i satyryczny ukazał renesansowe społeczeństwo oraz kondycję człowieka. Wyśmiał także scholastyków, dopuszczających się wielu nadinterpretacji Pisma Świętego. Ukazał przez to wysoki poziom swojej wiedzy teologicznej. Twierdził, że renesansowy człowiek nie jest już w stanie rozpoznać orędzia Chrystusa i nie wybiera go, tylko ignoruje i tym samym nie żyje w naśladowaniu Chrystusa, co staje się jego porażką.

9 Por. R. McInerny, A First Glance at St. Thomas Aquinas, London 1990, s. 7; R. Marius, dz. cyt., s. 82-83; J. Nelson, dz. cyt., s. 63-64. 
Największą krytyką objął tych, których misją było doprowadzenie wiernych do samego Chrystusa, czyli teologów i duchownych, w tym i papieża. Postępowanie tego ostatniego okazało się przeciwne duchowi philosophia Christi, jak również kłóciło się z przesłaniem Chrystusa w Ewangelii i jego uczniów. Jednym z głównych celów philosophia Christi było odkrycie miłości chrześcijańskiej. Z kolei Tomasz More dołączył do tego myśl, że chrześcijanie muszą wierzyć w dogmaty nieomylnego Kościoła. Tak więc połączenie przesłania Kazania na Górze z nauką Kościoła stanowi najlepsze rozwiązanie dla naprawy chrześcijańskiego społeczeństwa. Scalenie Biblii (w językach oryginalnych), pism Ojców Kościoła, dokumentów doktrynalnych i praktyki Kościoła katolickiego oraz humanistyczne narzędzie retoryki tworzyło - zdaniem More’a - najbardziej praktyczny program do przeprowadzenia reformy i pozwalało ostatecznie uzyskać wolne od zepsucia i w pełnej okazałości chrześcijaństwo. Trzeba podkreślić, że Tomasz wskazywał na retorykę, która może stać się o wiele bardziej użytecznym narzędziem przekazu Bożych wartości niż dialektyka, ponieważ prawdę powinno się tak przedstawić, aby ci, którzy się z nią spotkają - ukochali ją. Taki styl wymownej retoryki to najlepszy sposób przekonywania ludzi o odmiennych stanowiskach, szczególnie jako cel zreformowania społeczeństwa, państwa i Kościoła. Pojawiające się ludzkie przeszkody mogą być przezwyciężone dzięki chrześcijańskiej wspólnocie, opartej na filozofii Chrystusa. Utopia More’a to przykład zastosowania retoryki jako preferowanej metody perswazji w przyjemnym, wymownym i skutecznym wydaniu. Jest ona niejako kontynuacją tradycji humanistycznej przekazywanej przez Erazma, z ostatecznym celem reformy nie tylko Kościoła, ale chrześcijańskiego społeczeństwa jako całości. Dzieło to jest próbą odpowiedzi na pytanie, jak zreformować społeczeństwo na poziomie indywidualnym i instytucjonalnym ${ }^{10}$.

${ }^{10}$ Por. Desiderius Erasmus, Sileni Alcibiadis, [w:] Erasmus on His Times, red. M. Phillips, Cambridge 1967, s. 78-82; tenże, The Praise of Folly, London 1979, s. 44; E. Rummel, Erasmus and his catholic critics, Leiden 1989, s. 12-15; M. Hoffmann, Rhetoric and Theology: The Hermeneutic of Erasmus, Toronto 1994, s. 53-61. 


\section{REFORMA SPOŁECZEŃSTWA A SŁUŻBA KRÓLEWSKA}

Traktat Utopia jest uważany za wyraz dążenia do reform, obrony humanizmu erazmiańskiego i prezentacji philosophia Christi. W jej sercu jest podstawowe chrześcijańskie i humanistyczne przesłanie koniecznej potrzeby reform, których program stworzył T. More. Warto się zastanowić, dlaczego Tomasz tak poważnie zalecał radykalne zmiany w społeczeństwie angielskim, jak tolerancja religijna, dopuszczalność samobójstw, eutanazji i rozwodów, odrzucenie nadmiernego bogactwa wśród duchowieństwa. Określenie tego traktatu jako prostego programu do tworzenia idealnej wspólnoty byłoby czymś zbyt uproszczonym i jednowymiarowym. Opowiadanie się za tym, iż utopijne praktyki są lepsze od ówczesnych europejskich, zapewne miało na celu zachęcenie do poszukiwania sposobu zreformowania własnego życia, praktyk religijnych i instytucji. More dostrzegał w tym idealny sposób, w którym krytykując praktyki Starego Kontynentu, jednocześnie ukazał swój ideał, czyli społeczeństwo żyjące filozofia Chrystusa, na czele z władcami, pobożnymi i wykształconymi duchownymi oraz cnotliwymi ludźmi. Chciał najpierw, aby reforma dotyczyła wnętrza człowieka i to najlepiej wykształconego, a następnie społeczeństwa, w którym człowiek żyje, ponieważ - jego zdaniem - mądre osoby mogą zrozumieć, które zalecenia są rzeczywiście korzystne dla społeczeństwa, a które wyraźnie stoją w sprzeczności z Pismem Świętym i nauką Kościoła i są najzwyczajniej nie do przyjęcia. Tomasz, wzywając do reformy, chciał, aby ludzie prowadzili cnotliwe życie w społeczeństwie. Odnosząc się do tematu służby królewskiej na dworze Henryka VIII, był zdania, że aby społeczeństwo wyzwoliło się od zepsucia, obowiązkiem dobrych ludzi jako obywateli i chrześcijan jest służba u boku władcy. Pierwszym krokiem powinna być reforma konkretnych osób w Europie, począwszy od wpływowych ludzi, prowadząca do reformy społeczeństwa jako całości. Drugim krokiem ma być zachęta do reformy instytucji chrześcijaństwa, czyli Kościoła katolickiego, który w oczach More’a był konieczną składową dla funkcjonowania chrześcijaństwa w Europie i poza jej granicami ${ }^{11}$.

${ }^{11}$ Por. M. Martinez, Renaissance Visions of Paradise, „Sederi” 4 (1993), s. 121-124; T. More, Utopia, Cambridge 2003, s. 5-7. 
W kwestii królewskiej służby warto przyjrzeć się portretowi etycznemu Tomasza. Na pierwszy plan wysuwa się przywiązanie do rodziny i przyjaciół. W czasie służby u króla był z dala od swojej rodziny i twierdził, że potrzebuje towarzystwa dobrych znajomych, aby to pomogło mu znieść rozłąkę z jego domem, żoną i dziećmi, z którymi był wyjątkowo związany. Druga kwestia dostrzegalna w tym temacie w postawie angielskiego humanisty to miłość i lojalność wobec Ojczyzny i króla Henryka VIII, którego wychwalał jako najbardziej niezwyciężonego króla Anglii. W spotkaniu osoby żyjącej Bożymi zasadami z osobami różnych zasad na dworze królewskim może zrodzić się wątpliwość, czy jeśli taki człowiek rozpoczynający służbę jest świadomy, że jego słowa będą miały niewielki lub żaden wpływ na dobro publiczne, to jak ma postąpić w zaistniałej sytuacji? Tomasz był zdania, że nawet jeśli ów człowiek ma do czynienia z dużą odpornością na jego idee i przez to nie może dokonać istotnych zmian w kwestiach, w których jest zaangażowany, to nie może zaniechać swoich wysiłków, gdyż jest to obowiązkiem każdego człowieka kierującego się dobrem. Zadanie to jest trudne przez wzgląd na pojawiające się przeszkody, ale jest zadaniem koniecznym. More przekonywał, iż może on także swoją elokwencją i retoryką przyczynić się do duchowej reformy u innych wpływowych osób i społeczeństwo będzie zreformowane, gdy najpierw reformie poddadzą się władcy królestwa. Trudnością może być sytuacja, gdy królowie czy kardynałowie otoczeni są osobami źle na nich oddziałującymi, które mogą odrzucić propozycję nowych pomysłów, polityki i zmian, ponieważ przez to ich reputacja i wpływy będą zagrożone. Królewscy doradcy z dużym zaangażowaniem troszczyli się o własne dobro i pozycję, nawet jeśli wiązało się to ze szkodą dla państwa. Taki stan rzeczy w pewien sposób zrażał do podjęcia służby królewskiej. Trzeba zaznaczyć, że angielskie wyższe sfery dworu, nie licząc się ze zwykłymi obywatelami, odznaczały się drapieżnością i chciwością, jak również zamiłowaniem do luksusu. Obiektywnie rzecz biorąc, służba królewska nie powinna sprawiać, że oddany człowiek staje się jej niewolnikiem, ale odnajduje on w niej chęć angażowania się w dobro publiczne, a nie tylko myśl o swoich osobistych pragnieniach, jak i pewnego rodzaju ofiarę $\mathrm{w}$ niesienie pomocy innym ${ }^{12}$.

12 Por. T. More, dz. cyt., s. 16-18; A. Kenny, dz. cyt., s. 40-42. 
Według More’a rozwiązanie bolączek społeczeństwa nie sprowadza się do uchwalenia wielu przepisów prawnych, ale to zreformowanie wnętrza każdego, co dojdzie do skutku za pomocą humanistycznych metod i przyjęciu philosophia Christi. Ponadto jak długo serce jest wypełnione przez chciwość, pychę i inne zepsucia, społeczeństwo i poszczególni ludzie cierpią. Tylko niezachwiana wierność Bożym przykazaniom i odpowiedzialność liczy się w królewskiej służbie, a nie bieganie za zaspokajaniem własnych preferencji i pragnień, myśląc tylko o sobie. W związku z tym powstaje dylemat, do jakiego stopnia człowiek może żyć zgodnie z prawem własnego rozumu? Powinno się podjąć służbę, ponieważ społeczeństwo skorzysta $\mathrm{w}$ ten sposób z nowych pomysłów, a przez to przyczyni się do powiększenia wspólnego dobra publicznego. Tomasz porównał obowiązek króla do obowiązku pasterza. Pasterz jest wtedy dobrym pasterzem, gdy karmi swoje owce, a nie tylko dba o siebie. Tak więc istnieje obowiązek dobrego i mądrego człowieka oraz obowiązek dobrego króla. Zauważył również, że wprowadzenie w życie nowych pomysłów wśród tych, którzy są oporni na słuchanie, nie jest łatwą sprawą. Wtedy należy użyć narzędzia, jakim jest retoryka, ponieważ nie ma innej filozofii bardziej praktycznej dla mężów stanu. Nie można zdezerterować, gdy ktoś uparcie obstaje przy swoich racjach. Tak jak nie wolno opuścić statku podczas burzy, gdyż nie ma możliwości kontroli wiatrów. Poza tym nie należy wymuszać na ludziach nowych i dziwnych pomysłów, których realizacja byłaby bez większego znaczenia i bez przekonania o ich słuszności. Trzeba szukać i dążyć do najlepszych argumentów, aby klarownie rozwiązać problem. Nie jest rzeczą możliwą, aby wszyscy ludzie byli dobrzy, więc trzeba - na ile to realne - powiększać dobro ${ }^{13}$.

Warto zaznaczyć, że T. More i Erazm byli przekonani, iż pożyteczne i rozwijające jest czytanie dzieł chrześcijańskich humanistów, od których można się uczyć sztuki retoryki. Ich elokwencja przejawiała się przede wszystkim w sile przekonywania, kiedy starali się uczyć i bawić słuchaczy, aby ostatecznie przekonać do swoich racji, co było ich właściwym zadaniem. Renesansowi mówcy stawali się liderami na publicznych

${ }_{13}$ Por. J. Nelson, dz. cyt., s. 65-66; B. Mansfield, Erasmus and More: Exploring vocations, [w:] A companion to Thomas More, red. A. Cousins, D. Grace, New Jersey 2009, s. $145-148$. 
zgromadzeniach, mając tym samym władzę nad słuchaczami. Różnili się zdecydowanie od filozofów, a odgrywanie właściwej roli na scenie publicznej zawsze było wyzwaniem. Tomasz, opowiadając się za retoryką, porównał obowiązek służby publicznej do roli w sztuce. Należy ją przyjąć bez zbędnych pytań i bez obaw o pochwałę, choć pewnie bardziej pożądane byłoby występować bez słów, niż recytować tekst i popełnić błąd, robiąc galimatias komedii i tragedii. Cokolwiek człowiek odgrywa, powinien to wykonywać najlepiej jak potrafi i nie zakłócać tym prawidłowego przebiegu sztuki, przez co będzie miał większe zainteresowanie i podziw widzów. Życie ludzkie to występ na scenie i More doszedł do przekonania, że mądry człowiek nie powinien się uchylać od obowiązku służby bez poważnych konsekwencji. Można spróbować zdjąć kostiumy i makijaż $\mathrm{z}$ aktorów na scenie i pokazać ich widzom $\mathrm{w}$ ich własnym naturalnym wyglądzie, ale wtedy zepsułoby się całą sztukę. Wszystko nagle wyglądałoby inaczej - aktor, który grał kobietę, wydaje się mężczyzną; ten, który grał młodego człowieka, wygląda na starego; kto w sztuce był królem, w rzeczywistości jest biedakiem; aktor grający Boga faktycznie okazuje się nędznym człowiekiem. Dla Tomasza całe ludzkie życie jawiło się jako pewnego rodzaju sztuka na scenie świata, w której różne osoby wchodzą na scenę życia w różnych strojach i każdy gra swoją rolę, dopóki reżyser nie da wskazówki, aby opuścić scenę. Zdarza się, że jeden i ten sam aktor wchodzi na scenę w różnych strojach: najpierw grał króla, później wchodzi jako pokorny sługa. Trzeba podkreślić, że te metafory sceniczne miały na celu przekonanie, iż egoistyczne potrzeby dla osobistych przyjemności ma zastąpić obywatelski obowiązek służby ${ }^{14}$.

Wszystkie rzeczy, które przez przewrotną moralność ludzi wydają się dziwne i absurdalne, mają być usunięte, a dokona się to dzięki prawdziwemu życiu chrześcijan zgodnie z nauką Chrystusa. Bez wątpienia społeczeństwo odniesie największe korzyści, gdy przyjmie program Chrystusa, który w swojej mądrości i dobroci wiedział, co jest najlepsze dla człowieka i który stworzył wspólnotę opartą na służbie. Zdaniem More’a własna pycha uniemożliwia służenie państwu, społeczeństwu, przyjaciołom czy rodzinie, ponieważ ona jak wąż z piekła oplata się wokół ludzkiego serca i utrudnia jego rozwój. Tak więc celem zabiegów było

${ }^{14}$ Por. M. Martinez, dz. cyt., s. 127-130. 
nakłonienie do porzucenia własnej pychy i zaangażowanie się w społeczne reformy ${ }^{15}$.

\section{UTOPIJNE PRAKTYKI W ŚWIETLE KONCEPCJI REFORMY SPOŁECZEŃSTWA}

Podstawowym pytaniem było, co rzeczywiście konstruktywnego mógł zaproponować T. More społeczeństwu europejskiemu? Bezsprzecznie starał się zreformować zastany katolicyzm. Jednym z najbardziej kontrowersyjnych aspektów utopijnego społeczeństwa jest fakt, że jest to społeczeństwo komunistyczne. Dzielenie się wszystkim, co posiadają, od domów, które zmieniają co dziesięć lat, do żywności i ilości pracy, którą każdy musi wykonywać codziennie. Cała wyspa jest jak jedna rodzina i występuje ogólna pogarda dla pieniądza i widocznego bogactwa. $\mathrm{Na}$ pierwszy rzut oka owe praktyki stanowią przykład przesłania nowotestamentalnego, kierującego człowieka na potrzebujących i gromadzenie sobie skarbów nie na ziemi, ale w niebie (por. Mt 6,19-20). Można by rzec, że Dzieje Apostolskie ukazują pewien rodzaj komunizmu istniejącego u zarania Kościoła apostolskiego, gdy pierwsi chrześcijanie „trwali w nauce Apostołów i we wspólnocie, w łamaniu chleba i w modlitwach. Bojaźń ogarniała każdego, gdyż Apostołowie czynili wiele znaków i cudów. Ci wszyscy, co uwierzyli, przebywali razem i wszystko mieli wspólne. Sprzedawali majątki i dobra i rozdzielali je każdemu według potrzeby" (Dz 2,42-46). Różnica między praktykami w Utopii a chrześcijańskimi wynika z motywacji, którą się kierują. Kościół pierwotny praktykował zasadę wszystko wspólne przez wzgląd na dobra materialne, które były dla niego bez znaczenia, oraz dlatego, że nie mieli wątpliwości, iż Bóg zapewni wszystko, co będzie konieczne do głoszenia Ewangelii i misji Chrystusa. Optymalnym lekarstwem na pyszne pragnienie bogactwa jest chrześcijańska pokora, która rodzi się z wiary, nadziei zbawienia i miłości, wykorzeniając z ludzkiego serca pychę, niezgodę i smutek ${ }^{16}$.

${ }^{15}$ Por. T. More, dz. cyt., s. 160.

16 Por. tamże, s. 85-86; W. Campbell, Erasmus, Tyndale, and More, London 2007, s. 94-95. 
Odnosząc się do scholastycznych średniowiecznych teologów, w Utopii jest mowa, że poczucie szczęścia wiąże się ze zjednoczeniem pewnych zasad zaczerpniętych $\mathrm{z}$ religii, jak i z filozofii, używającej racjonalnych argumentów. Metody scholastyczne - zdaniem More’a - nie są aż tak bardzo korzystne dla sprawniejszego funkcjonowania społeczeństwa, choć niektóre z zasad tomizmu były do zaakceptowania. Przyjmując wspomniane zasady, iż przez naturalny rozum poszczególny człowiek i społeczeństwo może dojść do pewnych prawd, nie kierując się wiarą, Kościołem czy objawieniem orędzia Chrystusa, można tylko w ograniczonym zakresie przyjąć i zrozumieć owe prawdy, chyba że „niebo” (czyli w domyśle chrześcijaństwo) zainspiruje człowieka czymś bardziej świętym. Natomiast wizja przyjemności, która roztacza się w interesującym nas traktacie, związana jest z pogańską, hedonistyczną filozofią epikurejską. T. More, tak jak Erazm, był zdania, że chrześcijaństwo jako jedyne z wszystkich innych religii przynosi to, co wszyscy starają się osiągnąć na swój sposób, czyli prawdziwe szczęście. Dlatego trzeba, aby każda filozofia była zgodna z filozofia Chrystusa. Wówczas może być osiągnięty najlepszy stan wspólnoty ${ }^{17}$.

Kolejnym dziwnym zwyczajem w traktacie jest wizja małżeństwa i rozwodów. Małżeństwo, które jest przez całe życie, można przerwać przez zło cudzołóstwa. Podstawą do rozwodu i ponownego małżeństwa może być także złe traktowanie i wtedy winny współmałżonek traci prawo zawarcia nowego małżeństwa, pozbawiony zostaje praw i nałożony zostaje na niego obowiązek ciężkiej pracy przymusowej. Z życiorysu Tomasza wynika, że swoje małżeństwo potraktował bardzo poważnie nie tylko dlatego, że był to jeden $\mathrm{z}$ siedmiu sakramentów, ale także ze względu na relację do niego w Nowym Testamencie i w pismach patrystycznych. Nowotestamentalne przesłanie w tym temacie skupione jest na analogiach między Chrystusem jako Oblubieńcem i Kościołem jako Oblubienicą. Ten aspekt wzmocnił poglądy Tomasza na tę kwestię i zmotywował go przeciwko jakiejkolwiek zachęcie do polityki rozwodu. Nie do przyjęcia było również dla niego, iż władza świecka decyduje o problemie małżeństwa, ponieważ tradycyjnie leży to w kompetencji sądów kościelnych. Przyzwoleniem na wyspie są samobójstwo i eutanazja, choć jest to sprzeczne

17 Por. T. More, dz. cyt., s. 92; R. McInerny, dz. cyt., s. 69-72. 
z biblijną nauką, jak również z piśmiennictwem patrystycznym i praktyką Kościoła katolickiego. Wydaje się, że sposób stylu Tomasza w tym punkcie jest celowo prowokacyjny, ponieważ zachęca w tej sprzeczności między powyższymi praktykami a odpowiednimi zasadami moralnymi i religijnymi do realizacji właściwej postawy. Trzeba podkreślić, że w renesansowej Europie samobójstwo było uważane za coś bluźnierczego i przeklętego, a eutanazja była nazywana morderstwem, winowajców zaś karały władze kościelne i świeckie. Dla społeczeństwa chrześcijańskiego takie praktyki były niedopuszczalne. Na utopijnej wyspie, gdy idzie o samobójstwa, to jeśli ktoś się tego dopuścił bez uzyskania zgody kapłanów i senatu - nie można go potraktować z szacunkiem, ale wrzucić do bagna ${ }^{18}$.

Znawcy tematu podkreślali niebezpieczeństwo zbyt bliskiej konfiguracji rozumu i religii, ponieważ z jednej strony, utopijni kapłani łączyli razem religię, medycynę i retorykę, a z drugiej strony, religijne przywództwo utopii wpadało w skrajność, która była odrażająca dla szesnastowiecznego chrześcijaństwa. Sugestią More’a było przekonanie, że po pierwsze, rozum nie wystarcza w sprawach religii (odrzucenie scholastyki), a po drugie, nadprzyrodzone objawienie chrześcijaństwa i kierownictwo Kościoła wraz z wykształceniem humanistycznym stanowią niezbędne elementy pomyślności społeczeństwa. Z kolei temat wojny odzwierciedlał poglądy T. More’a na temat udziału w konflikcie zbrojnym. Przyznał, że jest ona potwornością, smutną koniecznością, a najmniej chluby państwu przynosi stała wojna. Niechęć do wojny zapewne wyrosła z wniosków płynących z Nowego Testamentu, jak również z własnego jego doświadczenia w tym zakresie w Anglii, utrzymującej się nieufności po Wojnie Róż i nieudolnych próbach króla Henryka VIII w konflikcie zbrojnym we Francji ${ }^{19}$.

Ważnym czynnikiem są przekonania religijne i praktyki, gdzie najbardziej znaczącym wyrazem Tomasza jest philosophia Christi. Religia, jaka została zaprezentowana w jego słynnym dziele, na pierwszy rzut oka podobna jest do europejskiego katolicyzmu, ale z pewnymi zasadniczymi różnicami. Zamiast jednej, jednolitej wersji chrześcijaństwa istnieją różne rodzaje religii, nie tylko na wyspie, ale także w każdym mieście. Przed

18 Por. T. More, dz. cyt., s. 111-112; J. Nelson, dz. cyt., s. 81-82.

19 Por. D. Baker, dz. cyt., s. 55-56; J. Gillingham, dz. cyt., s. 23-27. 
przybyciem Europejczyków na wyspę utopiści stopniowo odchodzili od wachlarza przesądów i zmierzali ku zjednoczeniu się w jednej religii, która wydaje się przewyższać resztę w swojej sensowności. Warto wspomnieć, że More uważał, iż nie jest wystarczające dla religii i społeczeństwa opieranie się wyłącznie na racjonalnej mądrości. Poprzez nauczanie i objawienie prawdziwej wiary wszystko stanie się jasne. Jeśli chodzi o tolerancję religijną, to niektórzy naukowcy byli zdania, że T. More przychylał się do owych tolerancyjnych praktyk. Jednakże Tomasz nie był za wolnością religijną, ponieważ nikt nie powinien cierpieć z powodu swojej religii. Prawo powinno być zgodne z prawem dla każdego człowieka, aby postępować zgodnie z religią według własnego wyboru ${ }^{20}$.

W przeciwieństwie do katolicyzmu, utopijna religia miała bardzo mało dogmatów, ponieważ założyciel był przekonany, że Bóg nie pragnie zróżnicowanego i rozdzielczego kultu i dlatego nie cieszyli go różnorodni ludzie o wielorakich poglądach, aby mogło być prawdziwe to, co wszyscy uznają za takie. Wierzył, że jeśli będzie traktowane to rozsądnie, w cichy i skromny sposób, to prawda ostatecznie zwycięży fałszywe religie. Po tym życiu wady będą ukarane, a cnoty nagrodzone. Ci, którzy nie zgadzają się z tymi podstawowymi przekonaniami, mają zakaz wyrażania swoich opinii w obecności ludu, jednakże mogą to uczynić prywatnie przed kapłanami i ważnymi osobistościami. Poleganie na rozumie, a nie na podstawie wiary, którą jest philosophia Christi, daje do zrozumienia, że More faktycznie nie opowiadał się za promowaniem takiego rodzaju systemu. Ludzki rozum i mądrość są niewystarczające i doprowadziły jedynie do zepsucia i degradacji społeczeństwa. Tomasz mówił nawet o pewnego rodzaju cichym doradztwie heretyków, realizowanym nie tylko przez chrześcijańskich humanistów, ale także przez przywódców kościelnych przed reformacją protestancką. Wolność religijna i tolerancja, ale także fanatyzm religijny w społeczeństwie nie są bezpieczne w odniesieniu do pokoju społecznego. T. More był zdania, że fanatycy są w stanie przekonać innych do swoich racji, a przez to oddalają siebie i innych od prawdy Kościoła katolickiego. Jeszcze w 1516 roku, przed wybuchem reformacji miał obawy przed konsekwencjami religijnymi szerzących się rozruchów osób dążących do reformy. W Utopii krytycznie oceniono lekkomyślność

${ }^{20}$ Por. T. More, dz. cyt., s. 133-135. 
religijną tych, którzy głoszą swoje poglądy, bez względu na czas, miejsce czy okoliczności. To ostatecznie okazało się przydatne w potępianiu heretyków przez More’a ${ }^{21}$.

Warto także wspomnieć stosunek angielskiego humanisty do duchowieństwa i ich odniesienia do społeczeństwa, które stało się poważnym problemem $\mathrm{w}$ jego polemicznych traktatach, gdy bronił Kościoła katolickiego i jego zwierzchników przed atakiem protestanckiej krytyki. Tomasz faworyzował te osoby, które prowadziły bez zastrzeżeń życie moralne i przestrzegały zasady postępowania zgodnie z kodeksem moralnym. W negatywny sposób określił tych, którzy płaszczyli się przed europejskimi duchownymi, przez co ujawnił swoje odczucia względem przywódców Kościoła. Ponieważ utopijni kapłani byli nadzwyczajnej świętości, to z tego względu stanowili rzadkość wśród zepsutych mężczyzn. Owi kapłani odgrywali ważną rolę w społeczeństwie, nie tylko w praktyce religii, ale w codziennym życiu. To był zapewne przykład wiary humanistów, którzy uważali, że religia powinna ogarniać każdy aspekt ludzkiego życia. W Utopii kapłani przewodniczyli kultowi Bożemu, sprawując obrzędy religijne i będąc cenzorami moralności, a być wezwanym lub skarconym przez nich było dla człowieka wielką hańbą. Funkcja kapłanów realizowała się także przez udzielanie rad i napomnień, natomiast sprawdzanie i wymierzanie kar przestępcom należało do gubernatora i innych urzędników państwowych ${ }^{22}$.

Ze względu na to, że utopijni kapłani są wybierani w sposób powszechny, cieszą się dużym szacunkiem w społeczności, której służą. Można sugerować, iż był to wyraz krytyki przepychu i sztywnej hierarchii europejskiego chrześcijaństwa. Bezpośrednie porównania utopijnego duchowieństwa $\mathrm{w}$ ich prawdziwej pobożności z zepsuciem ich europejskich odpowiedników rodziło żarliwą chęć zmiany, a nie kpiny i szyderstwa. Przez uwypuklenie wad duchowieństwa More zapewne miał nadzieję, że spowoduje to skorygowanie ich błędów i jednocześnie przywrócenie godność instytucji, której służyli. Poza świętością kapłanów są oni wolni od wszelkich świeckich kar, a jeśli dopuścili się jakiekolwiek przestępstwa,

${ }^{21}$ Por. tamże, s. 132-133; R. Marius, dz. cyt., s. 134-140.

22 Por. M. Lopez, The Life of the Essenes and the Life of the Utopians. A Case Study, „Moreana” 31 (1994), s. 43-45. 
to poddawani są nie sądowi, ale pozostawieni Bogu i sobie, ponieważ byłoby rzeczą niewłaściwą, aby ludzka ręka została podniesiona na winną osobę w szczególny sposób poświęconą Bogu. Można łatwo zaobserwować ich postawę, gdyż jest ich niewielu i są odpowiednio dobrani do swojej funkcji. T. More nie tylko poddawał krytyce błędy królów, ich doradców i duchownych, ale wskazywał na osoby świeckie i porównywał ich zachowanie do ludzi zamieszkujących utopijną wyspę. Dostrzegał, iż Europejczycy uczestniczą w Eucharystii, ponieważ mają to w nawyku i pokazują tylko zewnętrzną pobożność, a nie koncentrują się na prawdziwym znaczeniu liturgii i samego chrześcijaństwa. Natomiast utopiści odznaczają się o wiele większą wrażliwością sumienia w tym względzie. Jeśli są świadomi nienawiści lub złości wobec drugiego to - jak nauczał Jezus - nie przynoszą swojego daru do ołtarza, dopóki nie będą w zgodzie z bliźnim i nie oczyszczą serca, a wszystko to z obawy przed karą ${ }^{23}$. Oddziaływanie Chrystusowego Kazania na Górze obecne jest w nauce Erazma i More’a, którzy nawoływali chrześcijan, aby kochając Boga, wzajemnie się miłowali i traktowali się nawzajem jak prawdziwi uczniowie Pana, żyjący Ewangelią. Tomasz był zdania, że kierując się wskazaniami Kościoła i mając za przewodników pobożnych kapłanów, każdy człowiek jest w stanie przekonać osoby wokół siebie do dobrego życia i postępowania. Innymi słowy, philosophia Christi oddziałuje w taki sposób, iż przenika wszystkich obywateli w społeczeństwie, czyli władców, ich doradców, przywódców Kościoła i każdego człowieka. Byłoby błędem popieranie wszystkich religijnych praktyk utopistów, stojących w opozycji do chrześcijańskiego przesłania. W Utopii są pobożni kapłani i świeccy, ale brakuje im najważniejszego, czyli Biblii. Mimo wprowadzania greckich i łacińskich dzieł nie wprowadzono ani łacińskiego, ani greckiego Nowego Testamentu. Można sugerować, że takie zaniechanie jest wzmocnieniem niepewnej przyszłości utopijnego chrześcijaństwa, przy pozornej bliskości $\mathrm{z}$ erazmiańskim humanizmem. Trzeba zauważyć, że brak również katolickiego biskupa. Bez wątpienia ortodoksyjność religii i społeczeństwa w Utopii to owoc Erazmiańskich wysiłków na rzecz korzystania z Pisma Świętego i modelu wczesnej patrystyki jako narzędzi reformy. More dołożył wszelkich starań, aby dać do zrozumienia, że reforma jest osiągalna

${ }^{23}$ Por. T. More, dz. cyt., s. 139-140; D. Baker, dz. cyt., s. 69-70. 
dzięki odkryciu prawdy przez scholastyczny tomizm oraz że poganie tak jak utopiści muszą to połączyć z chrześcijańskim objawieniem i uzupełnić o takie aspekty wiary jak duchowieństwo, nauczanie i przewodnictwo Kościoła oraz starożytne teksty humanistów ${ }^{24}$.

Niewątpliwie wiele kwestii w Tomaszowym dziele jest bardzo absurdalnych, jak zwyczaje i prawa osób w metodzie prowadzenia wojny, obrzędach i religii, jak również $\mathrm{w}$ innych instytucjach oraz w głównym fundamencie całej struktury społecznej, czyli wspólne życie i egzystencja bez wymiany pieniędzy. Ten ostatni aspekt całkowicie obalał szlachtę, przepych, wspaniałość i majestat, które w ocenie zwykłych ludzi były prawdziwą chwałą i ozdobą państwa. Można sądzić, że pycha i pieniądze to nowe korzenie wszelkiego zła, na które lekarstwem w społeczeństwie była philosophia Christi. Jednakże łatwiej wyrazić życzenie, aby niektóre sfery w państwie zmieniły się, niż mieć nadzieję na ich realną zmianę. Tomasz przez odnoszenie się do pozytywnych i negatywnych aspektów społeczeństwa miał nadzieję, że reforma w niedługim czasie dojdzie do skutku i on sam dożyje dnia, kiedy wśród ludzi zapanuje prawdziwe dobro $^{25}$.

\section{PODSUMOWANIE}

Tomasz More przez cały czas utrzymywał swoje przekonanie, że aby zarówno poszczególnych człowiek, jak i całe społeczeństwo przetrwało i zostało zbawione, obywatele muszą podążać drogami Chrystusa i zdać się na prawowite przywództwo i powszechne prawo Kościoła katolickiego. Wskazanie na służenie sobie nawzajem było zaakcentowaniem humanizmu i podkreśleniem obowiązku mądrych ludzi służenia swoim rodakom i władcom. Później opowiadał się za służbą ogólnie chrześcijaństwu, a nie konkretnemu suwerennemu narodowi. Zawsze wspierał służbę i spełnianie swoich zobowiązań osobistych i publicznych, najpierw jako królewski doradca, a później jako dobry przywódca katolicyzmu okresu

${ }^{24}$ Por. T. More, dz. cyt., s. 140-143; J. Nelson, dz. cyt., s. 85-88.

${ }_{25}$ Por. T. More, dz. cyt., s. 151; J. Martínez, More’s Utopia or Utopia’s Utopia?, „Sederi” 4 (1993), s. 133-140. 
reformacji protestanckiej. Odrzucenie konkretnej metody reformowania nie jest ani niespójnością, ani sprzecznością, ani gwałtowną obsesją wobec innych. Trzeba zaznaczyć niektóre z podstawowych zasad humanizmu chrześcijańskiego, które zostały zilustrowane w traktatach Erazma i More’a. Wizja philosophia Christi tego ostatniego była na początku tożsama z założeniami humanisty z Rotterdamu, a mianowicie że ludzie powinni wywiązywać się z Jezusowego przesłania Kazania na Górze, aby kochać Boga i siebie nawzajem. Jednym z celów dążeń T. More’a było prowadzenie cnotliwego życia w społeczeństwie oraz wzywanie do reformy społeczeństwa i człowieka i branie aktywnego udziału w tej odnowie. Problem służby królewskiej miał szczególne znaczenie osobiste i zawodowe dla More’a. Niewątpliwe było jego przekonanie i zachęcenie po pierwsze, do reformy, poczynając od wpływowych osób (królowie i kardynałowie), prowadzące do społeczeństwa jako całości, a po drugie, do reformy instytucji chrześcijaństwa. W następstwie zatroszczył się on o świeckich katolików i o przesłanie humanistyczne. Jego zadaniem stało się również skorygowanie błędnych poglądów na korzyść ortodoksyjnej doktryny wiary, jak i ochrona ludzi niewykształconych i stabilności społeczeństwa. Nieustannie kładł nacisk na obowiązek służenia sobie nawzajem, opieki nad bliźnim i miłości Boga. Te dwa rodzaje miłości przejawiają się w nieprzekraczaniu prawa kanonicznego (wobec Boga) i byciu dyspozycyjnym (wobec bliźnich). T. More nigdy nie przestał wierzyć w to, że w swoim życiu świadomie dokonał właściwego wyboru, stając się męczennikiem prawdy, ponieważ jego wiara w zbawienie poprzez Chrystusowe cierpienie i śmierć doprowadziła go do przekonania, iż jego śmierć była jedynym rozwiązaniem, optymalnym w zaistniałych okolicznościach, i oznaczało to dla niego ocalenie chrześcijaństwa ${ }^{26}$.

Występujące we wspomnianym traktacie Tomasza praktyki mieszkańców takie jak rozwody, samobójstwa, eutanazja, łagodna religijna tolerancja były sprzeczne z nauczaniem Kościoła katolickiego. Wydaje się, że przez ten zabieg More chciał uzmysłowić, jak bardzo Kościół i Jego

${ }^{26}$ Por. R. Adams, The Better Part of Valor: More, Erasmus, Colet, and Vives, on Humanism, War, and Peace, 1496-1535, Washington 1992, s. 33-37; J. Tracy, The Low Countries in the Sixteenth Century: Erasmus, Religion and Politics, Trade and Finance, Ashgate 2005, s. 61-65. 
wierni powinni bezwzględnie poddać reformie swoje życie i zacząć żyć zgodnie z nauką Chrystusa. Z kolei liczne przykłady nowotestamentalne, z filozofii klasycznej i współczesnej mu literatury stworzyły skomplikowany i złożony obraz świata, w którym przyszło mu żyć. Należy powiedzieć, że jego dzieło nie odniosło reformatorskiego sukcesu w społeczeństwie europejskim, na jaki on sam liczył. Położył mocny nacisk na przemianę, w której znaczącą rolę odgrywa Kościół katolicki, duchowieństwo i ortodoksyjna doktryna. Jego dzieło stało się najostrzejszym sprzed reformacji napomnieniem $\mathrm{w}$ kwestii pogłębienia wiary i pobożności, jak i zachętą do wewnętrznej reformy.

Jak w świetle rozlewu krwi w czasie reformacji i kontrreformacji trzeba postrzegać T. More’a? Był przekonany, że spełnił w swoim życiu określone zobowiązania osobiste i publiczne przy boku króla Henryka VIII i jego religijnej dominacji. Tomasz w sposób świadomy pracował, aby jak najlepiej zrealizować owe zobowiązania. W tym wszystkim przyświecał mu chrześcijański humanizm i philosophia Christi. Jego życie i twórczość obejmowały bogactwo myśli historycznej, politycznej, literackiej i religijnej. Należy to rozumieć w kontekście kluczowych dla niego okresów, czyli renesansu humanistycznego i reformacji protestanckiej. Biorąc zaś pod uwagę zależność między jego religijnymi przekonaniami, polityczną rolą i osobistą filozofią, można w sposób bardziej precyzyjny wyciągnąć wnioski odnoszące się do okoliczności jego śmierci i do nowych perspektyw o jego miejscu w rozwoju nowożytnego państwa. Przesłanie T. More’a bez wątpienia daje lepsze zrozumienia współczesnego świata stojącego w obliczu podobnych wyzwań różnorodności i tolerancji. Warto zaznaczyć, że rola państwa we współdziałaniu religii i obywateli ma szczególne znaczenie w czasie, gdy wielu uważa, że swobody obywatelskie i religijne są naruszone przez rząd, obawiający się fanatyzmu religijnego. Patrzenie raczej przez pryzmat reformy i zrozumienia aniżeli strachu, nieufności i nienawiści jest niewątpliwie bardziej użyteczne niż oczekiwanie na nieuniknione skutki wykluczenia i zwalczania niektórych obywateli i ich przekonań. Poprzez zgłębianie wiedzy na temat takich struktur jak państwo, religia i zrozumienie społeczne, aby je rozwijać i korygować, można znaleźć sposób na realną zmianę na lepsze. 
Streszczenie. Artykuł dotyczy koncepcji reformy europejskiego społeczeństwa w duchu chrześcijańskiego humanizmu w ujęciu Tomasza More’a i zaangażowania się przez niego w to dzieło na dworze królewskim jako osoba kierująca się filozofią Chrystusa. W tym samym nurcie myślenia był Erazm z Rotterdamu. Obaj promowali założenia chrześcijańskiego humanizmu, którego celem było usprawnienie Europy, koncentrujące się na wartościach. Reforma odnosiła się do Kościoła katolickiego i społeczeństwa. T. More wierzył w zreformowanie ówczesnej Europy pod warunkiem przyjęcia przez ludzi humanistycznej edukacji, służenia sobie wzajemnie i postępowania według filozofii Chrystusa. Znaczący wpływ na kształt jego reformy niewątpliwie miał Erazm. W rozważaniach T. More’a pojawił się dylemat, czy człowiek roztropny i kierujący się Bożymi zasadami powinien wejść na drogę publicznej służby. Bez Biblii, jak i pomocy Chrystusa oraz Kościoła katolickiego żadne społeczeństwo nie może być naprawdę dobre. Kontrowersyjne praktyki występujące w „Utopii”, takie jak: społeczeństwo komunistyczne, wizja małżeństwa i rozwodów, przekonania religijne i praktyki i stosunek do duchowieństwa miały na celu wzbudzenie pragnienia reformy poszczególnych jednostek, jak i całego społeczeństwa. Z kolei wskazanie na służenie sobie nawzajem było zaakcentowaniem humanizmu i podkreśleniem obowiązku mądrych ludzi służenia swoim rodakom i władcom.

Słowa kluczowe: Tomasz More; Erazm z Rotterdamu; filozofia Chrystusa; chrześcijański humanizm; Utopia.

Abstract. Thomas More's concept of reform of the Christian society. The article concerns the concept of reform of the European society in the spirit of Christian humanism in terms of Thomas More and his involvement in the work of the royal court as the person directing the philosophy of Christ. In the same vein of thinking was Erasmus of Rotterdam. Both promoted the foundation of Christian humanism, whose aim was to improve in Europe, focusing on values. The reform referred to the Catholic Church and society. Thomas believed in reforming contemporary Europe, subject to acceptance by the people of humanistic education, to serve each other and to follow the philosophy of Christ. A significant impact on the shape of his reforms was undoubtedly Erasmus. In discussing Thomas appeared a dilemma whether a man wise and guided by God's principles should follow the path public service. Without the Bible, the help of Christ and the Catholic Church society can't be really good. The controversial practice appearing in "Utopia" such as communist society, the vision of marriage and divorce, religious beliefs and practices and attitude to the clergy were intended to arouse desire to reform individuals, and society. On the other hand pointing to serve each other was the emphasis on humanism and underlined the duty of wise men to serve his countrymen and sovereigns.

Key words: Thomas More; Erasmus of Rotterdam; philosophy of Christ; Christian humanism; Utopia. 